\title{
LOCAL CONSUMPTION OF AGRICULTURAL PRODUCTS IN BULGARIA
}

\author{
G. Aleksiev* \\ Faculty of Economics, Trakia University, Stara Zagora, Bulgaria
}

\begin{abstract}
Bulgarian agriculture has undergone several transformations at the end of the $20^{\text {th }}$ and the first two decades of the $21^{\text {st }}$ century. The ever-increasing use of modern technology has led to the concentration of production with a focus on oil seeds, corn, wheat, and other cereals. This form of development of the sector has led to the dependence on food imports for some of the major food groups.

The goal of this study is to analyze the local consumption of agricultural products in Bulgaria in order to draw a conclusion on any discrepancies between food supply and demand in the country. To achieve its goal, the study must focus on a few important topics: to analyze the food production structure in the country; to study the local consumption of agricultural products; to draw conclusions and offer development policies focused on sustainability.
\end{abstract}

Key words: agrarian sector, agrarian policy, agriculture, competitiveness, food security

\section{INTRODUCTION}

The accession of Bulgaria to the European union has brought some significant changes to the agricultural sector in the country. Many of the smaller producers have been forced out of the sector under the pressure of larger producers with access to the social support structure, that EU's CAP provides $(1,2)$. A large number of those smaller producers have been focused on productions with high labor intensity and comparatively higher profit margin. Those kind of production (fresh fruits and vegetables for example) due to their labor intensity have not been the focus of larger producer, that favor technological implementations and solutions (3).

All the for mentioned transformations have led to an increase in the level of imports of many of the major food groups and thus put the question of food safety in the country to the forefront of analysis. As part of the Common market, Bulgarian consumers have uninterrupted access to goods produced in other EU members and thus entertain the

*Correspondence to: G. Aleksiev, Faculty of Economics, Trakia University, Stara Zagora, Bulgaria, e-mail: georgi.alexiev@gmail.com proposition of food supply with high levels of quality and security (4), which for the time being dampens the issue of food security.

\section{METHODOLOGY}

The main methods used in solving the research problems and achieving the goal are: retrospective analysis, monographic method, comparative analysis, the method of expert evaluations, statistical methods of analysis, the method of modified calculations, the structural-functional method, calculation method, and others.

\section{RESULTS AND DISCUSION}

The consolidation of the Bulgarian agricultural sector and the specialization in the production of cereals and technical crops determine the leading role of large agricultural holdings.

In order to analyze the consumption of agricultural products, a detailed review of the production of some major food groups must be done.

Some of the most common agricultural products, traditional to the region are displayed in Table 1, with their yearly production for the period between 2014 and 2019. 
As previously stated, due to the concentration and increased mechanization in Bulgarian agriculture, the most produced agricultural product in the country is wheat and cereals in general. The production of cereals has increased during the studied period with the exclusion of a significant dip from 2014 to 2015. From 2015 onwards a steady improvement in produced quantities is evident by the data in Table 1 .
ALEKSIEV G.

While the production of cereals has increased through the studied period, the sunflower seed production has generally maintained its levels. The meat production has also maintained levels of 200 to 210 thousand tons on a yearly basis, with a slight increase in the last two years, although the projections for 2019 are with an inherent level of uncertainty.

Table 1. Crop and livestock production in Bulgaria (in 1000 t)

\begin{tabular}{|l|l|l|l|l|l|l|}
\hline CROPS/TIME & $\mathbf{2 0 1 4}$ & $\mathbf{2 0 1 5}$ & $\mathbf{2 0 1 6}$ & $\mathbf{2 0 1 7}$ & $\mathbf{2 0 1 8}$ & $\mathbf{2 0 1 9}$ \\
\hline $\begin{array}{l}\text { Cereals for the production of } \\
\text { grain (including seed) }\end{array}$ & 9674,49 & 8728,97 & 8945,12 & 9737,28 & 10110,55 & 11131,75 \\
\hline Wheat and spelt & 5458,99 & 5140,14 & 5942,78 & 6318,08 & 5954,52 & 6319,63 \\
\hline Rice & 52,66 & 65,12 & 62,54 & 59,60 & 60,72 & 70,92 \\
\hline $\begin{array}{l}\text { Potatoes (including seed } \\
\text { potatoes) }\end{array}$ & 132,65 & 164,87 & 127,18 & 227,71 & 261,69 & 197,41 \\
\hline Sunflower seed & 2019,51 & 1710,43 & 1853,83 & 2084,11 & 1943,98 & 1937,21 \\
\hline Soya & 0,76 & 41,92 & 19,13 & 20,91 & 4,73 & 7,57 \\
\hline Tobacco & 30,00 & 23,48 & 15,21 & 13,04 & 8,64 & 6,48 \\
\hline $\begin{array}{l}\text { Aromatic, medicinal and } \\
\text { culinary plants }\end{array}$ & 56,07 & 72,53 & 74,48 & 81,13 & 71,08 & 98,43 \\
\hline $\begin{array}{l}\text { Fresh vegetables (including } \\
\text { melons) }\end{array}$ & 389,65 & 433,79 & 664,21 & 554,91 & 574,59 & 551,05 \\
\hline $\begin{array}{l}\text { Permanent crops for human } \\
\text { consumption }\end{array}$ & 301,69 & 474,84 & 410,02 & 422,03 & 423,93 & 413,06 \\
\hline $\begin{array}{l}\text { Fruits, berries and nuts } \\
\text { (excluding citrus fruits, } \\
\text { grapes and strawberries) }\end{array}$ & $:$ & 213,02 & 198,93 & 219,59 & 228,46 & 234,47 \\
\hline White meats & 102,19 & 105,65 & 109,64 & 106,96 & 118,47 & $129,974 *$ \\
\hline Red meats & 98,23 & 99,65 & 102,72 & 104,27 & 109,70 & $115,132^{*}$ \\
\hline $\begin{array}{l}\text { Raw milk, total available on } \\
\text { dairies }\end{array}$ & 572,65 & 566,31 & 609,63 & 660,83 & 712,50 & 717,80 \\
\hline Cheese & 77,40 & 76,80 & 79,56 & 89,40 & 91,90 & 99,95 \\
\hline
\end{tabular}

Source: Own calculations based on data from Eurostat database, National statistics database and Agrostatistics $(*=$ projected data) $(9),(10),(11)$

During the whole studied period, the agricultural production in Bulgaria have been steadily increasing, due to the high efficiency orientated larger organization (5), that managed to implement modern techniques and technology. The only sector that has shown a steady decline is the production of tobacco which has been under considerable pressure due to decreasing demands for the produce as well as decreasing labor force in the region that traditionally is focused on those productions (6).

While production has been constantly improving the consumption of agricultural products has either maintained its levels or declining due to the steady decline in the nation's population (Figure 1).

The local consumption of some of the main foods in Bulgaria is visualized in Table 2. The largest consumption group is of bread and paste products that have been traditionally the main food group for Bulgarian consumers, especially bread. Although a part of the cereal production is used as fodder in animal husbandry that still forms only a small part of the produce. Most of the produced cereal is exported (7) and in later years Bulgaria has been one of the largest exporters of cereals. 


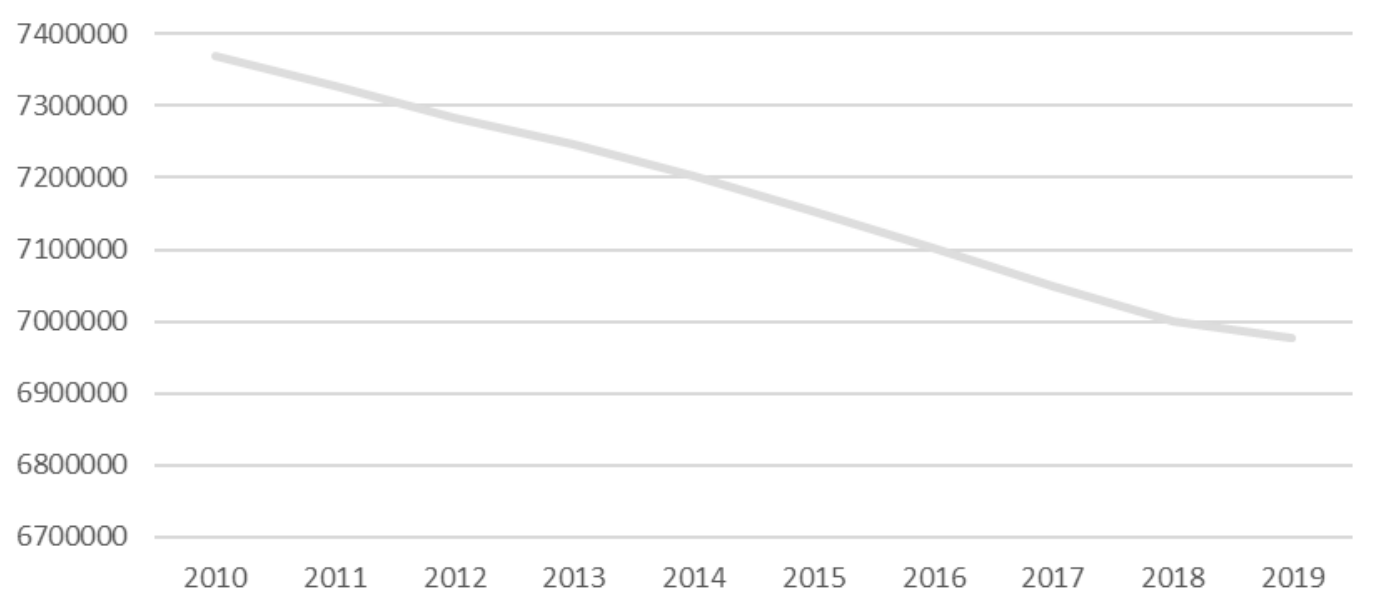

Figure 1.Bulgarian population

Source: National statistical institute of Bulgaria (11)

Table 2. Consumption of main foods in Bulgaria (in $1000 t$ )

\begin{tabular}{|c|c|c|c|c|c|c|c|c|c|c|}
\hline & 2010 & 2011 & 2012 & 2013 & 2014 & 2015 & 2016 & 2017 & 2018 & 2019 \\
\hline $\begin{array}{l}\text { Bread and } \\
\text { paste } \\
\text { products }\end{array}$ & 795,9 & $\begin{array}{l}781,8 \\
1\end{array}$ & $\begin{array}{l}736,4 \\
7\end{array}$ & $\begin{array}{l}708,6 \\
3\end{array}$ & $\begin{array}{l}671,2 \\
4\end{array}$ & $\begin{array}{l}640,2 \\
6\end{array}$ & $\begin{array}{l}624,9 \\
6\end{array}$ & $\begin{array}{l}614,0 \\
6\end{array}$ & 597,1 & 574,8 \\
\hline Rice & 51,59 & 51,29 & 48,08 & 48,55 & 46,09 & 42,92 & 43,32 & 41,60 & 40,60 & 39,76 \\
\hline Meat & $\begin{array}{l}235,8 \\
2\end{array}$ & $\begin{array}{l}235,2 \\
0\end{array}$ & $\begin{array}{l}233,1 \\
1\end{array}$ & $\begin{array}{l}233,3 \\
1\end{array}$ & $\begin{array}{l}234,0 \\
7\end{array}$ & $\begin{array}{l}233,2 \\
1\end{array}$ & $\begin{array}{l}230,8 \\
1\end{array}$ & $\begin{array}{l}231,2 \\
4\end{array}$ & $\begin{array}{l}240,1 \\
0\end{array}$ & $\begin{array}{l}249,0 \\
3\end{array}$ \\
\hline Milk & $\begin{array}{l}154,0 \\
2\end{array}$ & $\begin{array}{l}145,8 \\
1\end{array}$ & $\begin{array}{l}142,7 \\
8\end{array}$ & $\begin{array}{l}145,6 \\
4\end{array}$ & $\begin{array}{l}135,4 \\
0\end{array}$ & $\begin{array}{l}132,3 \\
5\end{array}$ & $\begin{array}{l}122,8 \\
6\end{array}$ & $\begin{array}{l}121,2 \\
6\end{array}$ & $\begin{array}{l}117,6 \\
0\end{array}$ & $\begin{array}{l}117,8 \\
9\end{array}$ \\
\hline $\begin{array}{l}\text { Fruit (fresh } \\
\text { and frozen) }\end{array}$ & $\begin{array}{l}320,5 \\
7\end{array}$ & $\begin{array}{l}345,8 \\
4\end{array}$ & $\begin{array}{l}335,0 \\
9\end{array}$ & $\begin{array}{l}364,4 \\
6\end{array}$ & $\begin{array}{l}363,7 \\
1\end{array}$ & $\begin{array}{l}340,5 \\
2\end{array}$ & $\begin{array}{l}347,9 \\
9\end{array}$ & $\begin{array}{l}357,4 \\
4\end{array}$ & $\begin{array}{l}346,5 \\
0\end{array}$ & $\begin{array}{l}362,0 \\
4\end{array}$ \\
\hline $\begin{array}{l}\text { Fresh and } \\
\text { frozen } \\
\text { vegetables }\end{array}$ & $\begin{array}{l}509,2 \\
3\end{array}$ & $\begin{array}{l}520,2 \\
3\end{array}$ & $\begin{array}{l}512,8 \\
3\end{array}$ & $\begin{array}{l}529,6 \\
6\end{array}$ & $\begin{array}{l}510,6 \\
4\end{array}$ & $\begin{array}{l}489,3 \\
2\end{array}$ & $\begin{array}{l}497,1 \\
3\end{array}$ & $\begin{array}{l}479,4 \\
0\end{array}$ & $\begin{array}{l}494,9 \\
0\end{array}$ & $\begin{array}{l}507,1 \\
4\end{array}$ \\
\hline
\end{tabular}

Source: Own calculations based on data from Eurostat database, National statistics database and Agrostatistics(9),(10),(11)

The local consumption needs for rice are met by the levels of production, as that is one of the most traditional products for the area. The locally produced rice has a very good reputation among Bulgarian consumers, and that drives the sales of the produce (8).

The production of meat has slowly caught up to the demand on the local market. There still is a 20 thousand tons deficit that is compensated by imports, mainly from other EU country members (Poland, Romania, etc.) (6). The consumption of meat has shown a steady level through the studied period, although the population have been steadily decreasing. This leads us to conclude that the consumption habits of the population are slowly changing, by replacing the relatively high levels of bread consumption with increasing levels of fresh fruit, vegetables and meat consumption.
Milk consumption has been steadily declining throughout the period which is not true for milk production. The excess of produced milk is used to produce dairy products that add additional value in the sector (5).

The consumption of fruits in Bulgaria is exceeding production by more than 125 thousand tons in 2019. This deficit is covered by imports of fresh, processed and frozen fruits from mainly neighboring countries (Greece and Turkey (3).

The production of fresh vegetables has slowly caught up to the levels of consumption in the country. There is a small number of exports and imports due to the demand for frozen vegetables, produced by a large organization outside of the country.

The local food consumptions have decreased in general, due to the decreasing population in the country. There are also some important trends 
in the supplementation of food groups among local consumers. The decreasing demand for dairy products, bread and fresh milk is based on the trends of healthier dieting of Bulgarian consumers. These products are exchanged in their diets by fresh fruits, vegetables and seeds. The local food market continues to be relatively small and doesn't have the capacity to realize all the locally produced foods, which forces a large amount of the producers to focus on export-oriented productions (6). While at the same time some of the local demands for processed fruits and vegetables are not met by the local producers, and that shortcoming should be the focus of expansion of the sector.

\section{CONCLUSION}

The local consumption of agricultural products has been generally decreasing during the studied period from 2014 to 2019 , mainly due to the decreasing population in the country. Food consumption habits and preferences of local consumers have been also changing and the demand for higher quality food products is steadily rising. The supplementation of unhealthier food groups with healthy alternatives in local consumer's diet has shifted some of the producers towards productions with higher added value that is both meeting the quality demand of consumers and economic efficiency and results demand of producers (8).

In order to improve the position of locally produced food on the market Bulgarian government has demanded for a specific area in supermarkets to be devoted to them. This decision has been met with pushback from stores, but with positivity by some consumers organisations.

In the future the local consumption of agricultural products will continue to model the improvement of the sector in order to build a solid foundation for the production of food with higher quality, that can meet local
ALEKSIEV G.

demands. Export oriented productions have been able to successfully build market relations and use the opportunities that the common market of the EU offers.

\section{REFERENCES}

1. Kostadinova, N. (2011). Ifluence of the eu common agricultural policy on the development of bulgarian animal husbandry. Trakia Journal of Sciences, 9(3), 18-22.

2. Petrova, N., Nencheva, I., \& Nikolov, R. (2011). Impact of bulgaria's accession to the eu on trade in agricultural goods. Trakia Journal of Sciences, 9(3), 36-39.

3. Nencheva, I., \& Petrova, N. (2010). Analysis and evaluation of the production and trade in fruits and vegetables. Trakia Journal of Sciences, 8(3), 223-229.

4. Kostadinova, N., \& Petrova, N. (2015). Issues and opportunities of bulgarian agriculture under the conditions of the common european market. Trakia Journal of Sciences, 13(1), 162-166.

5. Milev, O., Georgiev, I., Ivanova, D., Stoyancheva, D., \& Doncheva, D. (2019). Profitability in Bulgarian Food Industry: Influencing Factors and their Effects. Calitatea, 20(169), 145-150.

6. Nencheva-Ivanova, I. (2019). Realization of agricultural and food products on consumer markets. Trakia Journal of Sciences, 17(1), 299-306.

7. Nencheva, I., \& Hristova, R. (2011). Sale channels for fruits and vegetables in Bulgaria. Trakia Journal of Sciences, 9(3), 270-274.

8. Penev, N., \& Andreev, J. (2017). Financial and accounting aspects of the activity of bulgarian agricultural enterprises. Trakia Journal of Sciences, 15(1), 273-276.

9. Agrostatistics of the Ministry of Agriculture and food, Bulgaria

10.Eurostat

11. National statistical institute of Bulgaria 
